\title{
THE HYDROLOGICAL IMPACT OF THE PARANGANA DAM ON THE MERSEY RIVER, TASMANIA
}

\author{
by A. D. Knighton \\ (with five tables and six text-figures)
}

KNIGHTON, A.D., 1988 (31:x): The hydrological impact of the Paranagana Dam on the Mersey River, Tasmania. Pap. Proc. R. Soc. Tasm. 122(2): 85-96. ISSN 0080-4703. University of Sheffield, Sheffield S10 2TN, England.

By diverting the waters of the Mersey River into a neighbouring basin, the Parangana Dan changed the hydrological character of the downstream river. The flow records of three gauging stations, located at 10,67 and 88 $\mathrm{km}$ below the dam, provide the basis for identifying changes. Intermediate discharges have decreased the most and even at the furthest downstream station are $50 \%$ lower than before. The flow extremes, at both ends of the scale, have been less affected, and particularly the less frequent discharges which can be augmented by overspill. Indeed the highest flood on record, with a recurrence interval of over 500 years, occurred in the post-dam period. One-day and 30-day minimum flows are markedly lower downstream of the dam, but below the Dasher, the main tributary of the Mersey, they seem to recover and have almost regained pre-dam levels by the mouth. The entry of unregulated tributaries in the middle section separates a much changed upstream hydrology from a downstream one able to mitigate the worst effects of the dam except at intermediate discharges. In the upstream part, the physical, chemical and biological character of the river could be adversely affected by the altered flow regime, particularly in those reaches immediately below the dam.

Key Words: Mersey River, Parangana Dam, hydrological effects, Tasmania.

\section{INTRODUCTION}

Dams have been built for the purpose of river regulation for more than 4000 years but only in this century has the pace of construction accelerated. $1950-70$ has so far been the most significant construction period (Beaumont 1978), although the last decade has seen renewed activity. In North America and Africa up to $20 \%$ of total stream runoff is now regulated by reservoirs, with comparable figures for Europe and Asia of $15 \%$ and $14 \%$ respectively. The Australian figure is more modest at less than $5 \%$, but Tasmania is somewhat of an exception to other states in being rich in water resources.

Dam building for the purpose of power generation has been active there since 1895, with 1964-73 being the decade of maximum expansion. One of the most impressive schemes of that period is the Mersey-Forth Power Development which exploits the potential of the Mersey, Forth and Wilmot rivers in north-central Tasmania (fig. 1A). It consists of seven large dams, three major tunnels and seven power stations which generate over $300000 \mathrm{~kW}$. Its main significance for this study is that it involves the diversion of a major river - the Mersey. Dams are built for a wide variety of purposes but the complete diversion of such a large river is one of the more unusual. In effect, it represents river capture on a large scale.

The Mersey rises at a height of over $1000 \mathrm{~m}$ in the glacially deranged drainage of the Central Plateau where annual rainfall totals exceed $2000 \mathrm{~mm}$ (fig. 1A). Its profile down to the Parangana Dam is typical of many glaciated valleys, in that irregular convex steps alternate with poorly developed concave basins. For much of its course the river flows through steep and rugged country where the valley is relatively narrow and steep-sided gorges are not uncommon. One of those provided the site for the Parangana Dam, quartzite, schist, phyllite and slate being the dominant local rock types (Paterson 1971).

Work on the Mersey-Forth Power Development began in 1963 and the Mersey dams were completed in 1968 (Rowallan) and January 1969 (Parangana). Some power is generated at Rowallan but, in conjunction with the dammed headwaters of the Fisher, its main importance lies in storage and flow regulation for the power stations further down the system. Those stations are along the neighbouring River Forth, for the Parangana Dam diverts the flows of the Mersey and Fisher westwards through a $5 \mathrm{~km}$ tunnel. The 


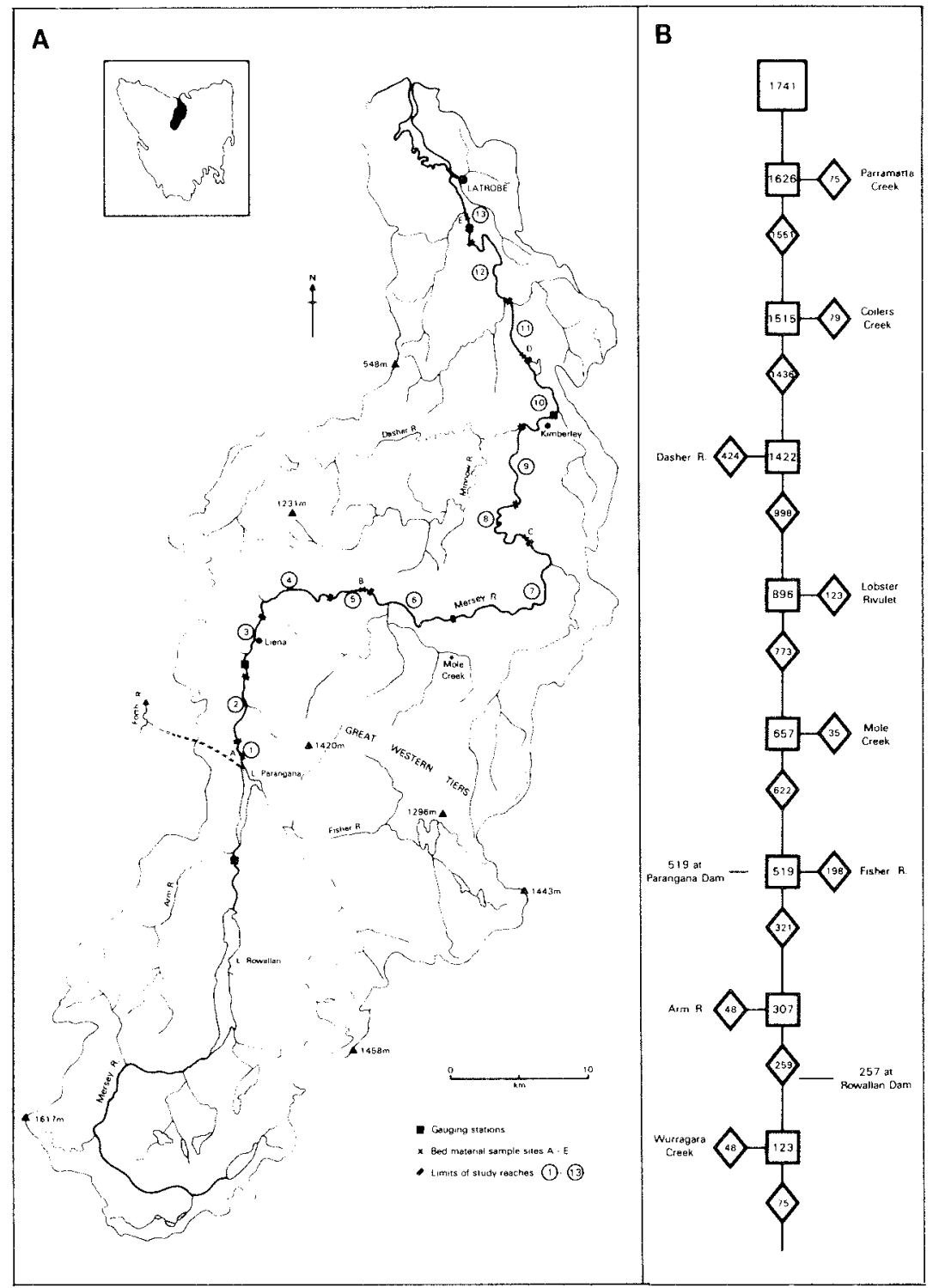

FIG. I-(A) The Mersey basin-the inset map shows its position in Tasmania. (B) The tributary structure of the Mersey system expressed in terms of network magnitude. Only the major tributaries are shown.

only discharges immediately downstream of the dam come now from occasional short-term releases and flood flows which exceed the capacity of Lake Parangana.

Reservoirs are known to influence the physical, chemical and biological character of the downstream river (Petts 1984, Lillehammer \& Saltveit 1984). Lake Rowallan, for example, has increased iron concentration sufficiently for the iron to be precipitated on the river bed (Tyler \& Buckney 1974). In this paper the hydrologic consequences of impoundment are the main concern. Unlike many such studies, this one not only deals with an unusual type of impoundment but also considers the impact along the entire downstream river, a distance of over $90 \mathrm{~km}$. The 
downstream propagation of effects is an area of particular uncertainty in the response of rivers to disturbance (Burkham 1981).

\section{CHANGES IN FLOW CONDITIONS}

Because of the various conditions for which dams are built and because each dam has its own release policy, a priori generalisations about the likely effects of a particular dam are difficult to make. A study of 29 dams in the United States revealed, for example, a wide range of responses as regards mean annual discharge (Williams \& Wolman 1984) - three increases, twenty decreases and six cases of no change. However, Petts (1984) has identified the most common consequences of impoundment - reduced average annual discharge, reduced seasonal flow variability, altered timing of annual extremes, reduced flood magnitudes, and the imposition of unnatural pulses. Some of these are present along the Mersey but not necessarily in a simple form.

Figure $\mathrm{IB}$ is a diagrammatic representation of the Mersey's tributary structure expressed in terms of magnitude, a topologic property defined as the total number of headwater sources or streams which ultimately feed a given section of river. At the Parangana Dam, a distance of $69 \mathrm{~km}$ from source, the river has lost $63 \%$ of its height, $41 \%$ of its drainage area and $30 \%$ of its final magnitude. Considered in terms of magnitude, therefore, flow additions from tributary sources below the dam are quite high and could be sufficient to mitigate the worst effects of the diversion, particularly downstream of the Dasher. However, according to the relationship between median annual flood $\left(Q_{2}\right.$ in $\left.\mathrm{m}^{3} \mathrm{~s}^{-1}\right)$ and drainage area $\left(\mathrm{A}_{\mathrm{d}}\right.$ in $\left.\mathrm{km}^{2}\right)$ for pre-dam conditions at eight sections in the Mersey and Forth basins:

$$
Q_{2}=7.7 A_{d}^{0.57}(\hat{\rho}=0.94)
$$

the potential loss in flow at the damsite is over 300 $\mathrm{m}^{3} \mathrm{~s}^{-1}$, which represents $95 \%$ and $76 \%$ respectively of the pre-dam median annual flood at the Liena and Kimberley gauging stations.

The downstream river is supplied from two sources other than tributary additions - infrequent controlled releases through a gated flume in the dam wall and uncontrolled overspills down an ungated spillway. The first are mainly intended to supplement very low discharges so that municipal, irrigation and industrial requirements can be met. The second are not directly quantifiable, but the fact that the potential loss calculated above is not realised at either Liena or Kimberley (table 1) suggests that they do make a large contribution during peak flow conditions. Certainly there was considerable overspill during the 1970 flood which devastated the Mersey valley.

This study is concerned with possible changes to both average and extreme flow conditions. It is based largely on the records of three gauging stations - Liena (1951-83), Kimberley (1945-83) and Latrobe (1963-77, 1982-83) - which respectively lie at distances of 10,67 and $88 \mathrm{~km}$ downstream of the dam, and have lost $94 \%, 36 \%$ and $31 \%$ of their natural network magnitude as a result of the diversion. 1969 is taken as the first year in the post-dam period. The years 1965-68 were excluded from the Liena and Kimberley analyses to avoid the risk of dam influence during the construction phase but, because of its shorter record, this was not possible for Latrobe. However, comparing 1965-68 with the other years in the pre-dam period at Liena and Kimberley, changes to the flow regime during construction can be regarded as quite small.

\section{Average Flows}

As a result of the flow diversion, mean annual discharge has decreased by $82 \%, 54 \%$ and $48 \%$ at Liena, Kimberley and Latrobe respectively, figures which correspond closely to the percentage loss in drainage area at the three stations - 94, 50 and 44. Compared with data for other impoundments (Petts 1984), these levels of reduction are very high, although decreases of $93 \%$ and $73 \%$ have been recorded $5 \mathrm{~km}$ and $112 \mathrm{~km}$ below the Conchas Dam on the Canadian River in New Mexico where almost all the water is also diverted (Williams \& Wolman 1984).

TABLE 1

Percentage Change in Flood Flows since Dam Closure

\section{Recurrence} interval (years)

Gauging station*

$\begin{array}{llc} & \text { Liena } & \text { Kimberley } \\ 1.11 & -93 & -67(-66) \\ 2 & -73(-70) & -34(-38) \\ 5 & -39(-55) & +14(-13) \\ 10 & -4(-52) & +58(+5)\end{array}$

* The bracketed figures give the percentage change with the 1970 maximum excluded from the post-dam series. 
Flow duration curves based on daily mean flows were constructed to show how the decreases break down at a more detailed scale (fig. 2). Such curves give the percentage of time during which any selected discharge is equalled or exceeded. Thus, the $1 \%$ flow is equalled or exceeded $1 \%$ of the time (or $0.01 \times 365=3.65$ days per year). The curves suggest that little change has occurred in the magnitudes of the ieast frequent flows, due partly to the effect of the very large 1970 flood. However, at Liena in particular, the pre- and post-dam curves rapidly diverge and even the $0.1 \%$ flow shows a large decrease at that gauge (table 2). The extent of the reduction increases markedly beyond the $5 \%$ flow, reaching a maximum for flows in the range of 40-90\% duration. Further downstream at Kimberley and Latrobe the maximum decrease is still considerable, in excess of $70 \%$ and $60 \%$ respectively, but tends to be more concentrated in the middle flow range (table 1). Mean annual discharge $\left(Q_{m a}\right)$ has become less not only in magnitude (fig. 3) but also in frequency - its duration has decreased from $33 \%$ to $14 \%$ at Liena, and from $34 \%$ to $26 \%$ at Kimberley and Latrobe. Thus, despite its smaller volume the average flow is now exceeded far less frequently. Not surprisingly Kolmogorov-Smirnov tests indicated that the distributions of mean daily flows differed significantly between the pre- and post-dam periods at all three stations.

The distribution of mean monthly discharges was used as the basis for determining whether, in association with the large decreases in daily and annual flow volumes, the seasonal pattern of flow has changed. Taking the pre-dam pattern as indicative of natural conditions, the flow regime was typically temperate oceanic with August as the month of maximum discharge. Interestingly, the

TABLE 2

\section{Percentage Change in Discharge of Various} Durations since Dam Closure

\begin{tabular}{lccc}
$\begin{array}{l}\text { Flow } \\
\text { duration } \\
(\%)\end{array}$ & Liena & Kimberley & Latrobe \\
\hdashline .1 & -45 & -5 & +11 \\
1 & -51 & -25 & -29 \\
5 & -65 & -45 & -35 \\
20 & -94 & -62 & -55 \\
50 & -96 & -71 & -65 \\
80 & -96 & -67 & -61 \\
95 & -94 & -51 & -47 \\
\hline
\end{tabular}

monthly flow distribution tended to become more peaked further downstream (fig. 3), suggesting that seasonal contrasts in precipitation and evaporation became more pronounced in that direction.

The Parangana Dam has accentuated the peakedness tendency at all three stations. If the gauging station on the Mersey upstream of the Arm River is used as a standard for comparative purposes (even though it lies downstream of Lake Rowallan), then the regime above the dam has changed little between the two periods apart from a slightly more even distribution throughout the year and a small increase in mean annual discharge, changes which are reversed downstream of the dam (fig. 3). All the gauges have developed a sharply peaked flow pattern, dominated by August, September and July. These months have experienced the smallest decreases in monthly discharge, ranging from $40 \%$ at Latrobe to $70 \%$ at Liena. In contrast, autumn (especially April and June) and spring have suffered the greatest losses as regards their contribution to the total flow regime. Such changes could affect the ecology of the river quite markedly. Indeed increased growth of freshwater algae has been reported upstream of Liena. Thus the dam has altered not only the magnitude of discharge but also the relative amounts of flow during the water year.

\section{Maximum Flows}

Average discharges, be they daily, monthly or annual, can conceal important features of flow behaviour associated with extremes, both high and low. It is not unusual to find that dams have little influence on average daily or annual discharges but significantly decrease annual peaks (table 4, Williams \& Wolman 1984, Andrews 1986). The mean annual flood is commonly reduced by more than 25\% (Petts 1984)

Flood flows are a particular concern since they represent a potential threat to structures and flood-plain land, and play an important role in the development of river channel form (Knighton 1984). Two modes of analysis are considered, based on series of annual maxima and sequences of high flows. The first uses the maximum instantaneous flow from each year of record to calculate the discharge $Q_{r}$ with a recurrence interval of $T$ years. In common with flood frequency analyses carried out in Tasmania (Watson 1975, Knighton 1987) and elsewhere (Benson 1968, NERC 1975), the log-Pearson Type III probability distribution was chosen for fitting curves to data 


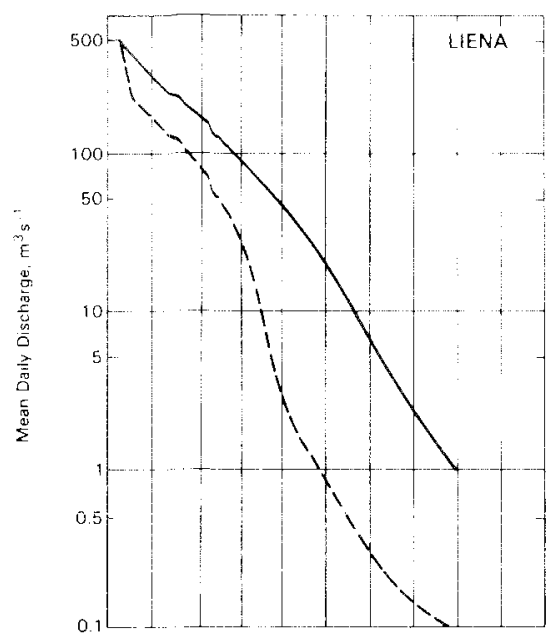

Pre Dan?

PoS1-Dan'11
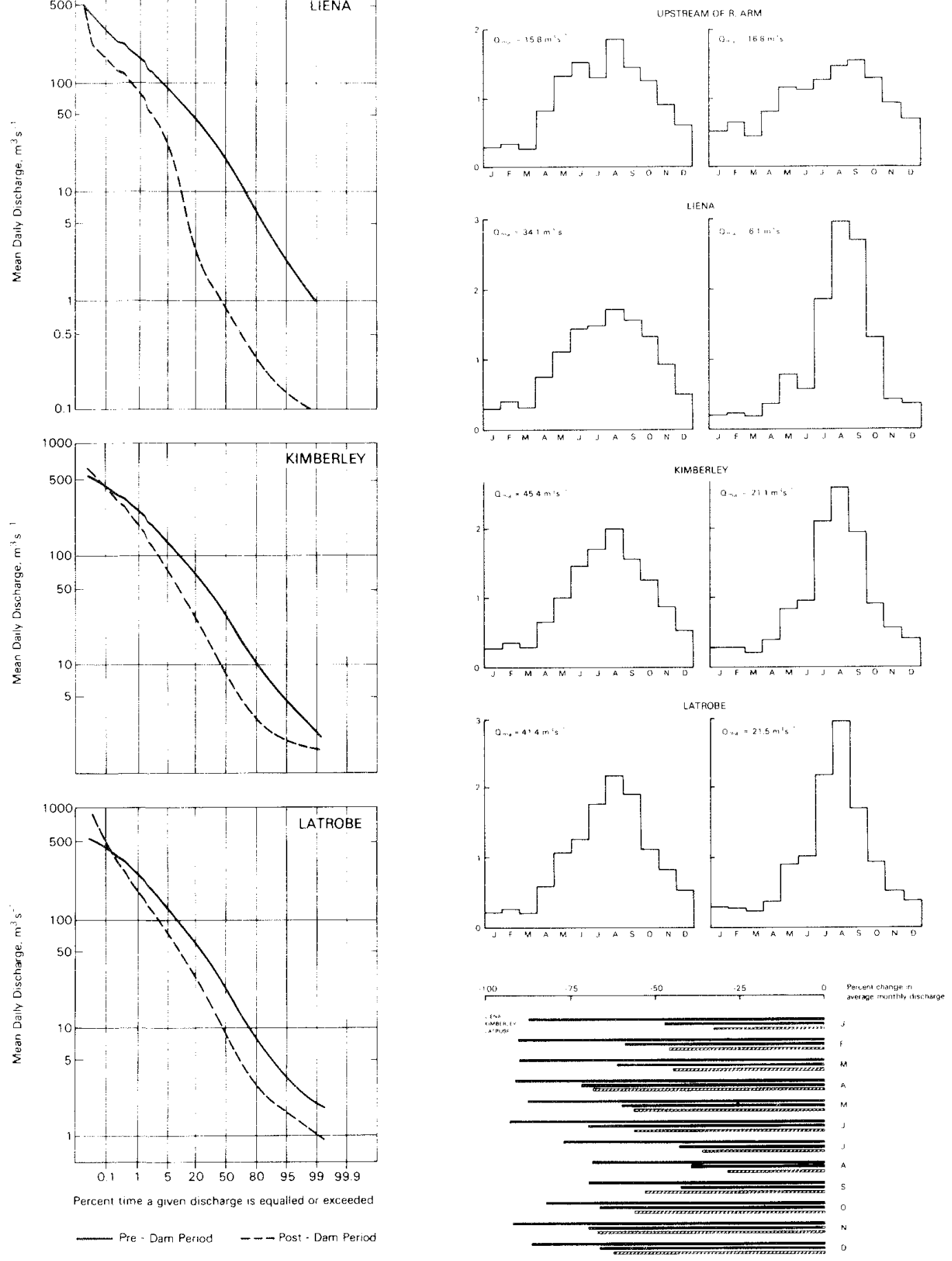

FIG. 2 - Pre-dam and post-dam flow duration curves for the Liena. Kimberley and Latrobe gauging stations.

FIG. 3 - Pre-dam and post-dam flow regimes defined in terms of monthly averages; vertical axis gives the ratio to the mean annual discharge $\left(Q_{m a}\right)$. 

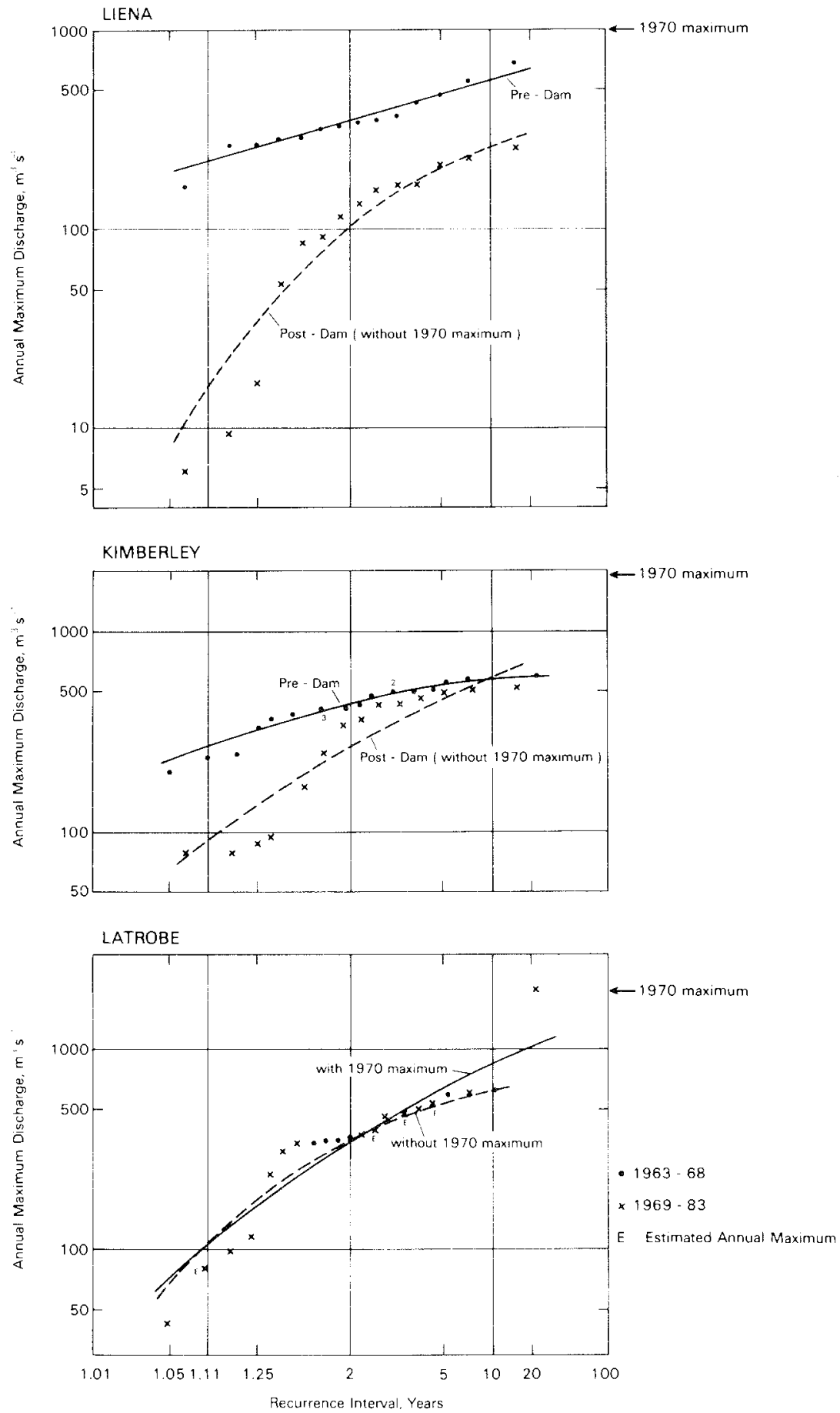

FIG.4-Flood frequency curves for the Liena, Kimberley and Latrobe gauging stations. The Latrobe data are not analysed in pre-dam and post-dam terms but as a single series. 
plots. At Liena and Kimberley the data were split into pre-and post-dam periods for separate analysis but at Latrobe the series was not long enough for such an approach. The data there were treated as a single series.

At Liena the pre-dam data are reasonably well described by a straight line but the post-dam data are distinctly skewed (fig. 4). The greatest difference between the two plots occurs at the lower end of the scale with a decrease in the more frequent flood values of over $90 \%$. Gradually the two series begin to converge but the difference between them beyond $Q_{2}$ depends on whether or not the 1970 maximum is included in the analysis (table 2). Despite the dam, that flood exceeded all previous records, fully occupying the spillway. It does not fit easily into the pattern formed by the other peak flows and its recurrence interval is consequently difficult to estimate in a reliable way. If the pre- and post-dam distributions are separately used for estimation purposes, then the flood would have a recurrence interval of 800 years and $>1000$ years respectively. In an upper level of the Marakoopa Caves, west of Mole Creek (fig. 1A), there is a stalagmite estimated at 9000 years old. In 1970 floodwaters occupied that level and stained the previously white stalagmite to a height of $0.75 \mathrm{~m}$, reinforcing the argument that the 1970 flood was indeed a very rare event. To provide a more realistic picture of the effect of the dam on flood flows, therefore, the 1970 flood was excluded. The resultant plot becomes sub-parallel with the pre-dam distribution beyond $\mathrm{Q}_{5}$, indicating a $50 \%$ reduction of flood magnitudes in the 5-20-year range.

At Kimberley also, the 1970 flood is a long way beyond previous experience, exceeding by $50 \%$ the maximum probable flood estimated just one year earlier (Steane 1969). Indeed, extending the curve of a total analysis (1945-83) gave an estimated recurrence interval for that flow of more than 1000 years. Again it is ignored in the postdam analysis. The plot of points in the post-dam period suggests the possibility of two separate data sets (fig. 4) - a low flood set where the decrease is more than $50 \%$, and an intermediate flood set (recurrence interval $>2$ years) in which the change from pre-dam conditions is relatively small. The curve for the post-dam period is a poor fit and tends to give a misleading impression of the degree of change, particularly at the ends of the scale (table 1). Nevertheless, it is not uncommon that the smaller, more frequent flood events are the ones to be decreased the most. Larger floods are less influenced by the containing effect of reservoir storage and may therefore be altered only to a negligible extent (Warner 1981).

The data for 1978-81 are missing from the Latrobe record and, in order to provide a complete series for analysis, peaks were estimated from an equation relating annual maxima at Kimberley and Latrobe (correlation coefficent of 0.99 ). The plot of points suggests that flood conditions have changed relatively little at this downstream station, although all the data in the lowest part of the range belong to the post-dam period (fig. 4). The effect of the dam on annual peaks above the median flood $\left(Q_{2}\right)$ seems to have been largely nullified at $90 \mathrm{~km}$.

Sequences of high flows provide another perspective, where the emphasis is more on maintaining a specified discharge level than attaining a particular discharge magnitude. Here a sequence is defined as the number of days in succession that daily discharge exceeds the $5 \%$ flow which, on average, is equalled or exceeded about 18 days each year. It should be remembered that discharge at this flow decreased everywhere along the river after closure of the dam (table 2), so that the comparisons of flow sequences are in any case based on different discharge values.

At Liena there were more than twice as many high flow sequences in the pre-dam period but they were significantly shorter (table 3) with less than $30 \%$ greater than 2 days in length. In producing better sustained but less frequent sequences, therefore, the dam seems to have had the effect of making the flow regime less flashy. It should be pointed out, however, that in the post-dam period the number of sequences has decreased dramatic ally after 1975. Of the 277 days on which the $5 \%$ flow was exceeded between 1969 and 1983, 236 occurred before 1976. Whatever the reason for that, be it climatic fluctuation or change in release policy, such a trend could have a major impact on the river in those reaches immediately downstream of the dam. Unwanted material is less likely to be flushed out of the system and may begin to concentrate up to deleterious levels.

Kimberley has the same basic pattern as Liena in that the sequence data suggest a flashier regime prior to the dam (table 3 ). However, the changes are less accentuated, the ameliorating effect of the Dasher being a major factor. Also, the distinction beteen $1969-75$ and $1976-83$ is less pronounced here. The trend of diminishing effect continues downstream so that by Latrobe pre- and post-dam sequence statistics are virtually identical (table 3). 
TABLE 3

Sequences of Days with Discharge above the $5 \%$ Flow

\begin{tabular}{|c|c|c|c|c|c|c|}
\hline & \multicolumn{6}{|c|}{ Gauging station } \\
\hline & \multicolumn{2}{|c|}{ Liena } & \multicolumn{2}{|c|}{ Kimberley } & \multicolumn{2}{|c|}{ Latrobe } \\
\hline & pre-dam & post-dam & pre-dam & post-dam & pre-dam & post-dam \\
\hline $\begin{array}{l}\text { Average length } \\
\text { of sequence }\end{array}$ & 2.3 & 4.8 & 2.1 & 3.4 & 3.1 & 3.2 \\
\hline $\begin{array}{l}\text { Number of } \\
\text { sequences }\end{array}$ & 87 & 39 & 58 & 55 & 57 & 48 \\
\hline
\end{tabular}

* A.ll data are reduced to a common time base of 10 years.

\section{Minimum Flows}

The other end of the flow scale is also important for a variety of reasons - the maintenance of water supplies, water quality, disposal of unwanted substances, and the provision of suitable conditions for fish and waterfowl. As with peak flows, two approaches are used to assess the impact of the dam - frequency analysis of annual minima, and sequences of low flows. The principles of the first are similar to those used above, but with the minimum flow for a given period being selected from each year of record. Two periods were chosen here - 1 day and 30 days. Thus, the 1 -day annual minimum is simply the lowest daily mean flow (expressed in $\mathrm{m}^{3} \mathrm{~s}^{-1}$ ) during the year, while the 30-day annual minimum is the average flow (again expressed in ${ }^{*} \mathrm{~m}^{3} \mathrm{~s}^{-1}$ ) over a 30 -day period with the lowest total yield during the year. The second may be a more representative indicator of low-flow conditions, especially as regards water supply.

The curves fit the Liena data reasonably well apart from a few negative residuals at the less reliable upper end of the recurrence scale (fig. 5). The change from pre-dam to post-dam conditions is almost the same for both flow periods (table 4) and represents at least as great a reduction as that produced in the annual maxima (table 1). In view of the contrast before and after 1976 indicated above by the high flow sequence data, a runs test was used to determine whether or not the minima in the post-dam period formed a random sequence or not. Despite a majority of below median values after 1976, neither the 1-day nor the 30-day sequence was significantly different from the random.
The Kimberley curves are even better fits (figure 5) and indicate much smaller decreases than at Liena (table 4). Unexpectedly both sets of curves tend to converge at higher recurrence intervals, indicating that the more extreme minima have been less affected. Of the two flow periods the 30 day one has experienced more change and that may be the one of greater relevance to water management. As at Liena, a runs test indicated no deviation from random in the sequence of post-dam minima.

Insufficent data prevented separate analysis at Latrobe but the distribution of points suggests that pre- and post-dam conditions belong to the same population (fig. 5). The main point to note is that the post-1969 data are better represented at the higher return periods where discharge values are lower.

A low-flow sequence is defined as the number of successive days on which mean daily

\section{TABLE 4}

Percentage Change in Annual Minimum Flows since Dam Closure

Gauging station

\begin{tabular}{lcccc} 
Recurrence & \multicolumn{2}{c}{ Liena } & \multicolumn{1}{c}{ Kimberley } \\
$\begin{array}{l}\text { interval, } \\
\text { (years) }\end{array}$ & $\begin{array}{c}\text { 1-day } \\
\text { minimum }\end{array}$ & $\begin{array}{c}\mathbf{3 0 - d a y} \\
\text { minimum }\end{array}$ & $\begin{array}{c}\text { 1-day } \\
\text { minimum }\end{array}$ & $\begin{array}{c}\mathbf{3 0 - d a y} \\
\text { minimum }\end{array}$ \\
\hline 1.11 & -89 & -90 & -47 & -66 \\
2 & -93 & -93 & -31 & -52 \\
5 & -94 & -93 & -21 & -37 \\
10 & -94 & -92 & -14 & -28 \\
\hline
\end{tabular}


discharge fell below the $95 \%$ flow given by the appropriate duration curve (fig. 2). The average length of such sequences varies little downstream with the stations having respective values of 9.2 , 10.3 and 9.1 days. Rather surprisingly the pre- and post-dam sequence data do not differ significantly in distributional or average properties at any of the gauging stations. The only noteworthy change was the increased frequency of low-flow sequences at Liena (from 15 per 10 years to 30 per 10 years). There is thus a contrast between the high-and low-flow analyses - the dam appears to have had larger impact on the magnitude of low flows (compare tables 1 and 4 ) but a significant effect on sequencing only in the high flow range.

\section{DISCUSSION AND CONCLUSION}

A dam represents a direct and immediate means of disturbing the existing regime of a river. Because of its diversionary role, the Parangana Dam has produced large decreases in almost all flows, the maximum change being in the intermediate flow range. Of the five commonest effects of impoundments listed by Petts (1984), reduced average annual runoff and smaller flood magnitude are the two which have most clearly resulted from the Parangana Dam. Additional effects include lower flow minima, and accentuated seasonal contrasts with the months of highest flow becoming more dominant (fig. 3).

Changes produced by impoundment can be transmitted over considerable distances. Through its effect on the flow regime of the River Nile, the Aswan High Dam has increased erosion potential in coastal areas more than $900 \mathrm{~km}$ downstream (Kashef 1981). Data for the Flaming Gorge Dam on the Green River show that, in common with many river regulation schemes, the range of daily mean flows has been significantly reduced and that, despite the entry of major tributaries below the dam, the effect remains substantial $500 \mathrm{~km}$ downstream (table 5). However, the data also indicate a progressive diminution of effect with distance at flows above the mean annual.

FIG. 5 - Frequency curves for 1-day and 30-day annual minimum discharges at Liena, Kimberley and Latrobe; the Latrobe data are analysed as a single series. Vertical axis is "annual minimum discharge in $m^{3} s^{\prime \prime}$.
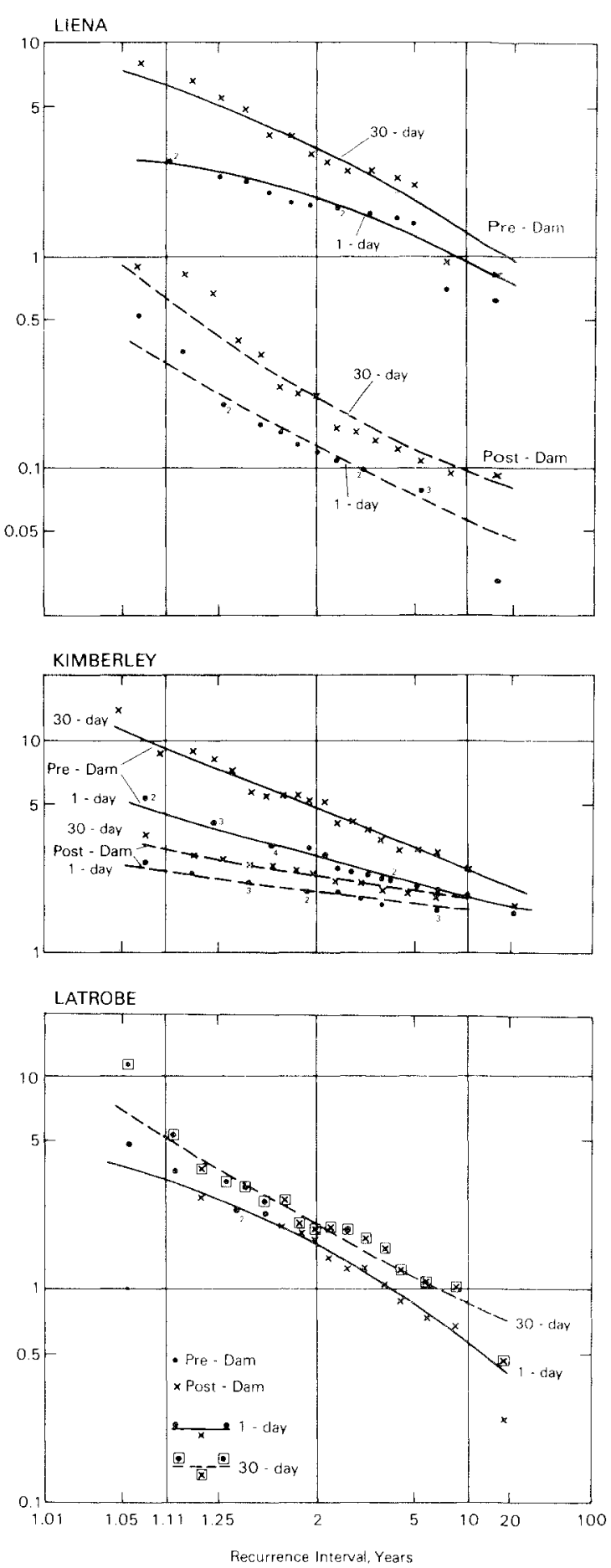

Recurrence Interval, Years 

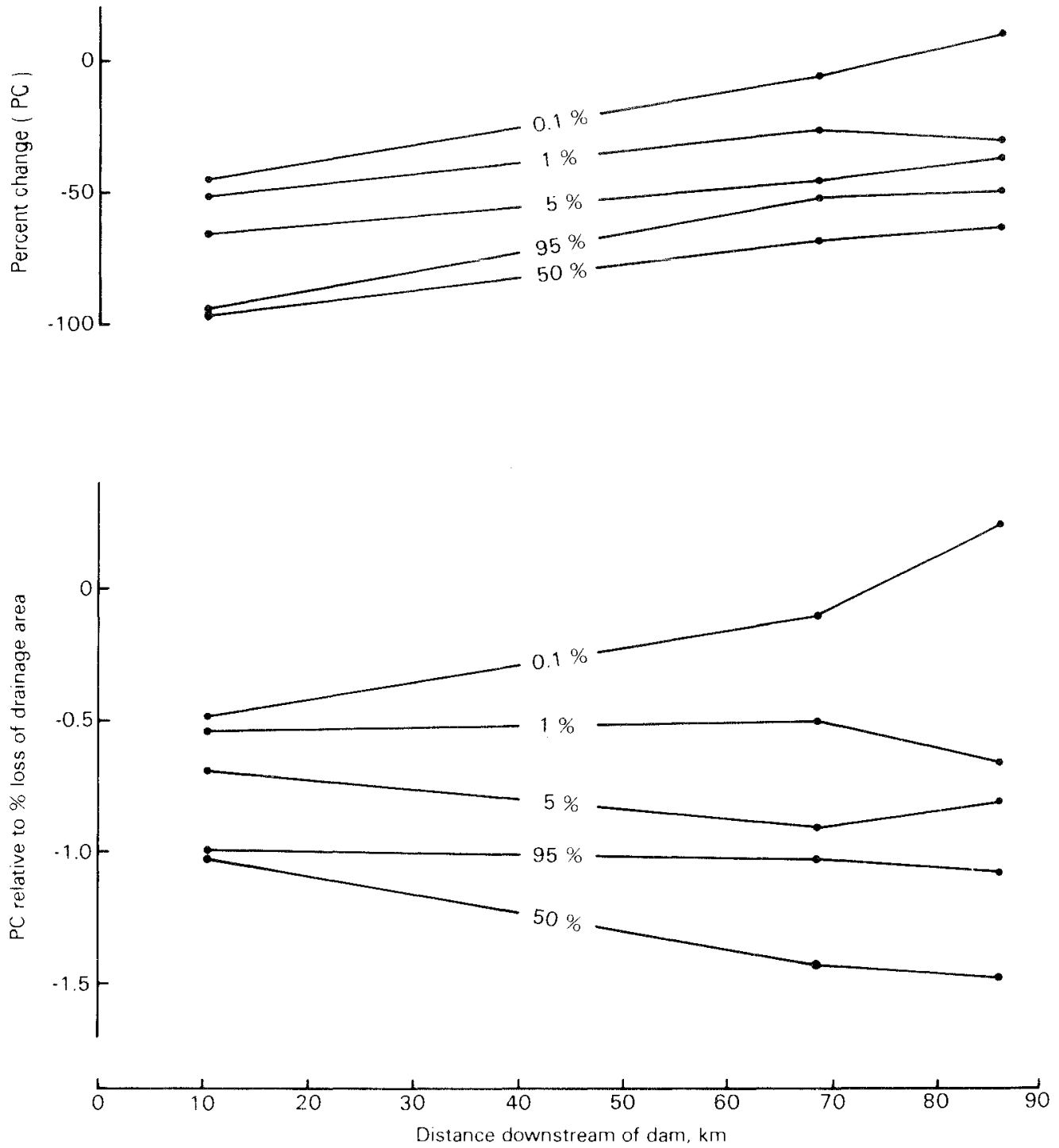

FIG.6-Percentage change and percentage change per unit loss of drainage area in various flow durations along the Mersey River below the Parangana Dam. The plots refer to flows with a low $(0.1 \%, 1 \%, 5 \%)$, intermediate (50\%) or high $(95 \%)$ duration 
TABLE 5

Percentage Change in Flow Conditions Downstream of the Flaming Gorge Reservoir on the Green River, Colorado and Utah (after Andrews 1986)

\begin{tabular}{lccc} 
Flow & $\begin{array}{c}\text { Greendale gauge } \\
(\mathbf{0}+\mathbf{k m} \\
\text { downstream) }\end{array}$ & $\begin{array}{c}\text { Jensen gauge } \\
(\mathbf{1 7 0} \mathbf{~ k m} \\
\text { downstream) }\end{array}$ & $\begin{array}{c}\text { Green River gauge } \\
(\mathbf{4 7 0} \mathbf{~ k m} \\
\text { downstream) }\end{array}$ \\
\hline $1 \%$ & -70 & -40 & -30 \\
$5 \%$ & -50 & -30 & -20 \\
Mean annual & 0 & -3 & -4 \\
$95 \%$ & +85 & +120 & +75
\end{tabular}

The Parangana Dam represents an extreme case in that it excludes all but the highest flows from the downstream river. In complete contrast to the Flaming Gorge Dam, the range of daily mean flows has actually increased, due largely to major reductions in intermediate and low-flow discharges (fig. 2, table 2). Not unexpectedly the gauge closest to the dam, at Liena (fig. 1), has experienced the greatest decrease but the effect of the dam on these flows remains large even at Latrobe, $88 \mathrm{~km}$ downstream, particularly when the change is expressed relative to the loss in drainage area (fig. 6).

Rather surprisingly in view of one of the major functions of dams, maximum flows have changed the least. Indeed the post-dam period has witnessed the highest flood on record (with a recurrence interval of over 500 years) and it seems that the Parangana Dam is performing only a limited flood control role. As regards the change in peak discharges, two characteristics stand out: the larger, less frequent floods have been the least affected; downstream recovery is much more rapid than for other discharges (fig. 4, table 1) - the more extreme floods may actually have increased in volume further downstream (fig. 6). These characteristics can be attributed firstly, to the role and limited capacity of Lake Parangana which, being a storage reservoir for power generation, is kept at a high level so that there is limited space for accommodating input flows at times of peak runoff; and secondly, to the large runoff contributions from unregulated tributaries below the dam, notably the Dasher (fig. 1). The Mersey is somewhat unusual in having such a large tributary magnitude in the lowest third of its course. That may partly explain why in the pre-dam period the river often peaked at
Kimberley before it did at Liena and why on several occasions after 1969 peaks at Kimberley and Latrobe had no equivalents at Liena.

One-day and 30-day minima have been severely reduced by the dam but these low flows do seem to recover reasonably well and by the mouth have almost regained their pre-dam levels. Undoubtedly the contributions from the Dasher and other tributaries are the major factor in the way that minimum as well as maximum flows recover in the lowest parts of the river. Herein lies a contrast, between the lower and upper Mersey, as regards the impact of the dam. In the latter, downstream tributaries compensate to a surprising extent for the diversion of headwater runoff. In the former, and particularly in reaches $1-5$ (fig. 1), the decreases in minimum and average flows are so severe that several deleterious effects could ensue. Agricultural wastes may build up and affect the quality of the water. Stagnant pools could become significant breeding grounds for insect populations, especially since flushing discharges are now less frequent at the relevant season and colder headwaters have been diverted. Certainly increased algal growth is a feature of the river above Liena. In function and effect the Parangana Dam is an atypical example of impoundment. Its impact on the physical, chemical and biological character of the Mersey needs to be carefully monitored, since it is far from being fully realised.

\section{ACKNOWLEDGEMENTS}

I would like to thank the following: The Royal Society and the University of Sheffield Research Fund for financial assistance; Dr Les 
Wood, the Head of the Departmentof Geography, University of Tasmania, for providing study facilities; Messrs M. Williams and S. J. Paterson of the Hydro-Electric Commission for their help with hydrological and survey data; Douglas Steane of the Rivers and Water Supply Commission for introducing me to the area; Pat and Harry Young of Echo Valley for their hospitality in the study area; and finally my wife, Celia, for her valuable field assistance.

\section{REFERENCES}

ANDREWS, E.D., 1986: Downstream effects of Flaming Gorge Reservoir on the Green River, Colorado and Utah. Bull. Geol. Soc. Amer. 97: 1012-23.

BEAUMONT, P., 1978: Man's impact on river systems: a world-wide view. Area 10: 38-41.

BENSON, M.A., 1968: Uniform flood frequency estimating methods for federal agencies. Water Res. Res. 4: 891-908.

BURKHAM, D.E., 1981: Uncertainties resulting from changes in river form. J. Hydraul. Div. Am. Soc Civ. Eng. 107(5): 593-610.

KASHEF, A.-A.I., 1981: Technical and ecological impacts of the High Aswan Dam. J. Hydrol. 53 $73-84$.

KNIGHTON, A.D., 1984: FLUVIAL FORMS AND PROCESSES. Arnold, London: $218 \mathrm{pp}$.

KNIGHTON, A.D., 1987: Streamflow characteristics of north-east Tasmania: I Regional flood flows. Pap. Proc. R. Soc. Tasm. 121: 23-33.
LILLEHAMMER, A. \& SALTVEIT, S.J. (Eds), 1984 REGULATED RIVERS. Proceedings of the Second International Symposium on Regulated Streams. Oslo: $540 \mathrm{pp}$.

NERC, 1975: FLOOD STUDIES REPORT. Natural Environment Research Council, London: 4 volumes.

PATERSON, S.J., 1971: Engineering geology of the Lemonthyme hydro-electric scheme, Tasmania. Civ. Eng. Trans., Institution of Engineers, Australia, April 1971:17-24

PETTS, G.E., 1984: IMPOUNDED RIVERS. Wiley, Chichester: 326 pp.

STEANE, J.D., 1969: The lower Mersey-Forth area and Rubicon River. Water Res. Surv., 11th Report, Rivers and Water Supply Commission, Tasmania: $63 \mathrm{pp}$.

TYLER, P.A. \& BUCKNEY, R.T., 1974: Stratification and biogenic meromixis in Tasmanian reservoirs. Aust. J. Mar. Freshw. Res., 25 299-313.

WARNER, R.F., 1981: The impacts of dams and weirs on the Hawkesbury-Nepean River system, NSW Australia. Paper presented at the $2 n d$ International Conference on Fluvial Sediments, University of Keele, U.K., 21-25 September 1981

WATSON, B., 1975: Flood magnitude and frequency Part 1: West Coast of Tasmania, Annual Flood Series. Hydro-Electric Commission, Investigations Division Reportt: 9 pp.

WILLIAMS, G.P. \& WOLMAN, M.G., 1984 Downstream effects of dams on alluvial rivers. U.S.G.S. Prof. Pap. 1286: 83 pp.

(accepted 12 February 1988) 